\title{
ENERGY SUPERPOWER IN WAITING: New Pipeline Development in Canada, SOCIAL LICENCE, AND RECENT FEDERAL ENERGY REFORMS
}

\author{
Peter Forrester, ${ }^{*}$ Kent HowIE AND Alan Ross ${ }^{* *}$
}

\begin{abstract}
A growing lack of public confidence in governmental regulation of business has created a climate in which industry must go beyond obtaining mere regulatory approvals for new projects: a "social licence" must also be acquired from stakeholder groups. This article explores the concept of social licence in the context of current pipeline project proposals. Governments play a significant role in this debate, as social licence is intertwined with the Canadian regulatory scheme. The authors address different models of regulatory reform, and explore how recent federal amendments have altered the social licence and regulatory landscape.
\end{abstract}

\section{TABLE OF CONTENTS}

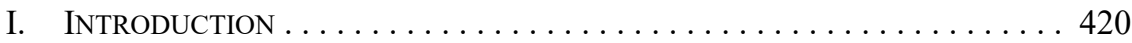

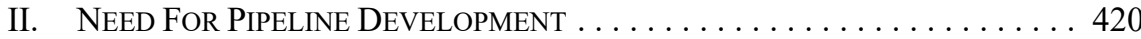

III. CURRENT PIPELINE PROJECTS AND OPPOSITION IN CANADA $\ldots \ldots \ldots 421$

A. Trans Mountain Pipeline Expansion Project $\ldots \ldots \ldots \ldots .421$

B. EnBRidge ............................... 422

C. TransCanada PiPelines Limited . . . . . . . . . . . . . . . 424

IV. IMPORTANCE Of Social LiCENCE In THE PIPELINE Debate $\ldots \ldots \ldots 426$

V. History and Definition of Social LicENCE $\ldots \ldots \ldots \ldots \ldots \ldots . . \ldots 27$

VI. CRiticism of the Social Licence Phenomenon . . . . . . . . . . . . . . 429

VII. Challenges IN THE SeARCH For Social Licence $\ldots \ldots \ldots \ldots \ldots 430$

VIII. Why SOCIAL LICENCE HAS BECOME

Prominent in the PiPeline Debates $\ldots \ldots \ldots \ldots \ldots \ldots \ldots \ldots 431$

IX. IMPORTANCE AND ROLE OF GOVERNMENT

in the Social Licence Debate $\ldots \ldots \ldots \ldots \ldots \ldots \ldots \ldots \ldots . \ldots 45$

X. The Problems of Existing Regulatory Structure AND PUBlic InTEREST TEST . . . . . . . . . . . . . . . . . 437

XI. OVERVIEW OF 2014-2015 FEDERAL REGULATORY REFORMS

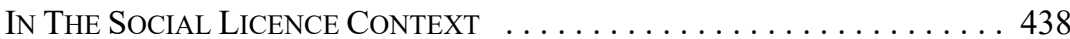

A. Regulatory Models $\ldots \ldots \ldots \ldots \ldots \ldots \ldots \ldots \ldots \ldots \ldots \ldots$

B. Key 2014-2015 PiPeline AND Social LiCENCE AMENDMENTS _.. 441

C. What ChOICES Do the 2014-2015 FederaL

REGULATORY REFORMS REFLECT? . . . . . . . . . . . . . . . . . . . . 443

XII. SOCIAL LiCENCE ROLE FOR BUSINESS LAWYERS . . . . . . . . . . . . . . 447

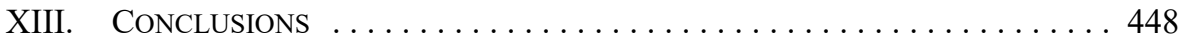

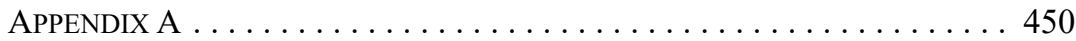

** $\quad$ Peter Forrester is a Senior Director, Legal \& Aboriginal Affairs, Kinder Morgan Canada Inc.

Kent Howie and Alan Ross are partners at the Calgary office of Borden Ladner Gervais LLP. The assistance of Leanne Desbarats and Billie Fortier Neufeld in the preparation of this article are gratefully acknowledged. 


\section{INTRODUCTION}

Former Prime Minister Stephen Harper proudly announced Canada's intention to become a world energy superpower in 2006, shortly after becoming Canada's 22nd Prime Minister. ${ }^{1}$ However, a lack of international market access for Canada's oil and gas has, to date, prohibited the country from fully monetizing its large energy reserves and becoming such a superpower. A number of pipeline projects intended to access American, Asian, and European energy markets have been proposed in Canada to help solve this problem.

Historically, these kinds of pipeline projects were tested by federal or provincial regulators using general public interest tests enshrined in governing legislation. Pipeline developers could rely on a positive regulatory decision as the primary licence needed to proceed with the development of their projects. Today, there is a growing lack of public confidence and trust in government and governmental authorities to do the "right thing" in regulating business. There is also an acknowledgment that pipeline development is inextricably linked to natural resource development in Alberta's oil sands and the related environmental issues. Accordingly, more stakeholder groups are lining up against pipeline developers and their proposed pipelines. Many of these stakeholders suggest that a traditional "regulatory licence" is no longer enough, and that a "social licence" must also be obtained from a broader stakeholder group before a new pipeline can be built in Canada. The result is that some pipelines are going undeveloped, not for the lack of a legal licence, but rather for the lack of a social licence.

Recent amendments to the National Energy Board Act ${ }^{2}$ and Canada Oil and Gas Operations $\mathrm{Act}^{3}$ on pipeline safety and security, as part of the federal government's broader Responsible Resource Development Plan, ${ }^{4}$ could assist pipeline developers in the search for this social licence — but are the amendments enough? In answering this question, this article explores the need for new pipeline development in Canada, the meaning of "social licence," the challenges posed for pipeline developers in their search for a social licence, and the choices made by the federal government in its recent reforms that might help pipeline developers obtain a social licence.

\section{NeEd For Pipeline Development}

The oil and gas sector is the leading recipient of private investment in Canada, and energy exports are the largest contributors to the country's positive trade balance. ${ }^{5}$ However, severe limitations on pipelines' ability to reach tidewater limit international energy market access for Canadian oil and gas. Canadian energy export issues are exacerbated in the current climate of low oil prices by growing shale plays in the US, which further reduce the demand

Stephen Harper, "Address by the Prime Minister at the Canada-UK Chamber of Commerce" (delivered at the Canada-UK Chamber of Commerce, London, UK, 14 July 2006), online: Office of the Prime Minister <pm.gc.ca/eng/news/2006/07/14/address-prime-minister-canada-uk-chamber-commerce>. RSC 1985, c N-7 [NEBA]. RSC 1985, O-7 [COGOA].

Government of Canada, "Responsible Resource Development-Overview," online: Canada's Economic Action Plan $<$ www.actionplan.gc.ca/en/page/r2d-dr2/overview $>$.

Statistics Canada, "Exports of goods on a balance-of-payments basis, by product" (Ottawa: SC, 2015), online: <www.statcan.gc.ca/tables-tableaux/sum-som/101/cst01/gblec04-eng.htm>. 
for Canadian production. There is currently an oversupply of oil in the Midwestern US which results in a continuing price differential between US pricing, reflected in the West Texas Intermediate (WTI) index, and international oil prices under the Brent Crude Index. ${ }^{6}$

Western Canada Select (WCS) is comprised of heavy conventional and bitumen crude oils from Western Canada that are blended with diluents. The majority of WCS is exported to the US from Alberta. ${ }^{7}$ The discount on Alberta oil - the phenomenon often referred to as the "bitumen bubble" - has been costly. In 2013-2014, WCS sold at an average 27 percent below WTI. ${ }^{8}$ The result is an industry facing a "double discount." In addition to the divergence between WCS and Brent prices, there is also a significant differential between WCS and WTI. ${ }^{9}$ To put the economic impacts into perspective, former Alberta Premier Jim Prentice stated "Alberta's oil not accessing tidewater in the last fiscal year saw lost revenue for energy companies of $\$ 10.85$ billion." 10

\section{Current Pipeline Projects and OpPosition in Canada}

There are currently five main pipeline proposals to bring WCS to tidewater. Those projects are Kinder Morgan Canada's (Kinder Morgan), the Trans Mountain Expansion Project (Trans Mountain), Enbridge Inc.'s (Enbridge) Northern Gateway and Line 9, and TransCanada Pipelines Limited's (TransCanada) Energy East and Keystone XL. Each company has encountered obstacles in their respective approval processes including regulatory overlap, environmental hurdles, and stakeholder and public opposition. These projects and their social licence challenges are described in further detail below and at Appendix A of this article. The proposed pipeline routes are set out diagrammatically at Appendix B.

\section{A. Trans Mountain Pipeline Expansion Project}

Trans Mountain twins an existing pipeline from the Edmonton, Alberta area to Burnaby, British Columbia. The expansion proposal adds an additional 540,000 barrels per day (bpd) to increase total capacity of the existing pipeline to $890,000 \mathrm{bpd} .{ }^{11}$ Kinder Morgan initially filed a project description with the National Energy Board (NEB or Board) on 24 May 2013. Its application for a Certificate of Public Convenience and Necessity pursuant to section 52 of the NEBA requires permits and approvals from nine federal regulatory agencies in addition

George Hoberg, "The Battle Over Oil Sands Access to Tidewater: A Political Risk Analysis of Pipeline Alternatives" (2013) 39:3 Can Pub Pol'y 371 at 372.

Alberta, Office of Statistics and Information, "Heavy Crude Oil Reference Prices, Monthly" (Edmonton: OSI, 2015), online: < finance.alberta.ca/aboutalberta/osi/aos/data/Heavy-Crude-Oil-Reference-Prices. pdf>.

Michael Babad, “Alberta's loathed 'bitumen bubble' slams Canada's rich province," Globe and Mail (8 March 2013), online: <www.theglobeandmail.com/report-on-business/top-business-stories/albertasloathed-bitumen-bubble-slams-canadas-rich-province/article9500410/> . As a further example, in 2014, Western Canada Select's average price "was US\$12.21 per barrel lower than the average price of Maya," a heavy crude benchmark from Mexico of similar quality to WCS (ibid).

Hoberg, supra note 6 at 372.

Yadullah Hussain, "Alberta Premier Jim Prentice says lack of access to oil markets cost province \$6billion," Financial Post (3 December 2014), online: < business.financialpost.com/news/energy/albertapremier-jim-prentice-says-lack-of-access-to-oil-markets-cost-province-6-billion>.

Kinder Morgan Canada, "Trans Mountain Expansion Project: An Application Pursuant to Section 52 of the National Energy Board Act" (December 2013) vol 2 at 2-1, 2-16, online: National Energy Board $<$ www.neb-one.gc.ca/fetch.asp?language $=$ E\&ID $=$ A3S0Q8 $>$ [Kinder Morgan Section 52 Application]. 
to British Columbia, Alberta, and municipal regulatory requirements. ${ }^{12}$ The NEB is currently reviewing the project with a report to the federal Cabinet expected in the first quarter of 2016.

Trans Mountain faces opposition from certain First Nations and environmental groups. The project even played a significant role in the 2013 British Columbia election. ${ }^{13}$ Kinder Morgan has undertaken successful stakeholder engagement, evidenced by mutual benefits agreements with at least 20 First Nations. ${ }^{14}$ However, the Trans Mountain project is still facing opposition from the "Tsleil-Waututh First Nation, whose traditional territory touches on the project's end at the Westridge marine terminal in Burnaby." 15

Project opposition is not limited to First Nations. On 2 September 2014, the City of Burnaby's employees “stationed themselves at Trans Mountain's worksite on Burnaby Mountain." 16 In 2014, the City of Burnaby also brought an application before the British Columbia Supreme Court seeking an injunction preventing Kinder Morgan from undertaking any further work in the Burnaby Mountain Conservation Area. The application and subsequent appeal were dismissed. The City then filed an application to the Federal Court of Appeal for leave to appeal a ruling of the NEB which allowed Trans Mountain employees access to the Burnaby Mountain site to undertake project studies. ${ }^{17}$ The decision further prohibited city workers from interfering with the Trans Mountain project or its employees. When Trans Mountain workers were met at the site by protestors, Kinder Morgan applied for and received injunctive relief from the British Columbia Supreme Court. ${ }^{18}$

\section{B. ENBRIDGE}

\section{NORTHERN GATEWAY}

The Northern Gateway project includes an export pipeline carrying an average of 525,000 bpd of oil product west from Bruderheim, Alberta to the marine port of Kitimat, British Columbia. ${ }^{19}$ Enbridge filed its application with the NEB in May 2010. First Nations' concerns about the project were diverse and significant. Northern Gateway engaged over 80 First Nations communities during its application process. ${ }^{20}$ After a protracted hearing, in

Ibid at 2-7-2-9; NEBA, supra note 2.

Hoberg, supra note 6 at 382-85.

Derrick Penner, "Trans Mountain project signs 20 First Nation agreements, but opposition remains," Vancouver Sun (12 February 2015), online: <www.vancouversun.com/business/Trans+Mountain+ project+signs+First+Nation+agreements+opposition+remains/10809556>.

Ibid.

Burnaby (City) v Trans Mountain Pipeline ULC, 2014 BCCA 465, [2015] 5 WWR 747 at para 9 (refusing leave to appeal to BCCA).

17 Re City of Burnaby and Trans Mountain Pipeline ULC (23 October 2014), MO-122-2014, online: NEB $<$ docs.neb-one.gc.ca/ll-eng/llisapi.dll/fetch/2000/90464/90552/548311/956726/2392873/2449981/2541 380/A97\%2D3\%2D_Order_MO\%2D122\%2D2014_\%2D_A4D6H2.pdf>, leave to appeal to FCA

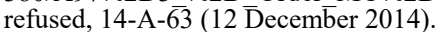

18 Trans Mountain Pipeline ULC v Gold, 2014 BCSC 2133, 92 CELR (3d) 258.

19 Canada, National Energy Board, Connections: Report of the Joint Review Panel for the Enbridge Northern Gateway Project, by Sheila Leggett, Kenneth Bateman \& Hans Matthews, Catalogue No NE23-176/2013E-PDF (Calgary: NEB, 2013) vol 1 at 3, online: NEB < gatewaypanel.review-examen.gc.

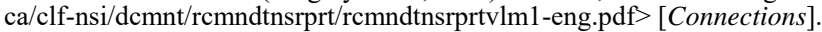

20 Enbridge Northern Gateway Pipelines, "Enbridge Northern Gateway Project: Update to Sec. 52 Application" (June 2011) vol 5A, online: NEB < docs.neb-one.gc.ca/ll-eng/llisapi.dll/fetch/2000/90464/ 90552/384192/620327/624798/692099/B24-2_-_Volume_5A_-_Aboriginal_Engagement_Update__June_2011_A1Z6R1_.pdf>. 
2013 the NEB Joint Review Panel approved the project subject to 209 conditions that must be met before construction begins. ${ }^{21}$

Northern Gateway continues to face significant legal obstacles. First Nations initiated ten proceedings at the Federal Court of Appeal against the Northern Gateway project. ${ }^{22}$ These proceedings challenge, among other things, the adequacy of consultation and whether the Crown met its duty to consult and sufficiently accommodate First Nation interests. As a result of very strong environmental and First Nations' opposition, more than five years after being initially announced, Northern Gateway remains controversial, with many industry watchers suggesting that it may ultimately never be built. This is despite the fact that Enbridge received the NEB conditional approval that it sought for the proposed project.

Northern Gateway also faces political headwinds. Premier Rachel Notley, elected on 5 May 2015, indicates that Alberta's New Democratic Party (NDP) government will not advocate for the Northern Gateway or Keystone XL pipelines. ${ }^{23}$ Support from a new leftleaning government in Alberta, coupled with a potentially different approach to greenhouse gas regulation, might have facilitated greater social acceptance for Northern Gateway. It now appears to have a more limited chance of proceeding, absent political support from the province which would predominantly benefit from access to tidewater.

\section{LINE 9}

Enbridge's Line 9 proposal involved the reversal of a pipeline previously shipping imported crude oil from Montreal, Quebec to Sarnia, Ontario. It reversed the flow to take WCS from Sarnia to Montreal, with capacity on the reversed line of 300,000 bpd. ${ }^{24}$ The project was divided into two phases. The NEB approved the first, shorter phase (Sarnia to Westover, Ontario) on 27 July 2012. On 6 March 2014, the Board approved Enbridge's Line 9B application with 30 conditions, to: (1) reverse the segment of Line 9 between North Westover, Ontario and Montreal; (2) expand the entire Line 9 capacity from Sarnia, Ontario to Montreal; and (3) revise the Line 9 Rules and Regulations Tariff to allow for the transportation of heavy crude on Line $9 .^{25}$

On 6 February 2015, the Board approved Enbridge's outstanding conditions on valve placement and watercourse crossing management plans with regard to the Line 9B Reversal and Line 9 Capacity Expansion Project. ${ }^{26}$ At the same time, the Board imposed additional obligations. At the time of writing, further regulatory steps were still required before Line 9 and Line 9B could be operational. Enbridge must apply for, and be granted, final leave to open. A leave to open application would involve a Board assessment of whether it is safe to put the pipeline into service (that is, to reverse the Line 9B portion, increase the capacity of

Connections, supra note 19 at 71.

Forestethics Advocacy Assoc v Canada (AG), 2014 FCA 182, 2014 FCA 182 (CanLII).

Alexander Panetta, "Alberta NDP election win gets noticed in US," CBC News (8 May 2015), online: $<$ www.cbc.ca/news/elections/alberta-votes/alberta-ndp-election-win-gets-noticed-in-u-s-1.3067504>. Re Enbridge Pipelines Inc (6 March 2014), OH-002-2013 at 28, online: NEB < docs.neb-one.gc.ca/11eng/llisapi.dll/fetch/2000/90464/90552/92263/790736/890819/2431831/2428616/Reasons_for_ Decision_OH-002-2013_-_A3V1E4.pdf?nodeid=2431830\&vernum=-2> [Re Enbridge].

Ibid at $1, \overline{3}, 131-40$.

26 NEB, "Enbridge Pipelines Inc. - Line B Reversal and Line 9 Capacity Extension Project (OH-0022013)," online: <www.neb-one/gc.ca/pplctnflng/mjrpp/ln9brvrsl/index-eng.html>. 
the entire Line 9, and to allow transportation of crude oil). There is no time limit for the Board's review.

Despite being almost entirely a pipeline reversal with very limited new build, the Line 9 project faced significant delay due to challenges from project opponents. That opposition arose from urban and suburban interveners in Toronto and Montreal, a group not previously as vocal in the initial Line 9 development. It demonstrates that pipeline project opposition now takes many forms including not only First Nations and environmental groups, but also landowners who might have previously ignored or simply accepted pipeline and utility development.

\section{TransCanada Pipelines limited}

\section{KeYstONE XL}

"The Keystone XL Pipeline is a proposed 1,179-mile (1,897 km), 36-inch-diameter crude oil pipeline beginning in Hardisty, [Alberta], and extending south through Steele City, [Nebraska]," and to the Texas GulfCoast. ${ }^{27}$ The Keystone system, if built, would have a total capacity of 1,291,000 bpd. ${ }^{28}$ Notwithstanding relatively light regulatory treatment in Canada, the US portion of the pipeline has been controversial. On 19 September 2008, TransCanada submitted an application for a Presidential Permit for the Keystone XL pipeline project. The US Department of State issued a Final Environmental Impact Statement on 26 August 2011, finding that the construction and normal operation of the project would not result in significant impacts along the proposed corridor. ${ }^{29}$ The project has been subject to numerous subsequent delays at both the US Congressional and Presidential levels and even played a role in the 2012 US Presidential election. ${ }^{30}$

Keystone XL faced immense opposition, turning what was projected to be a two-year application process into an over six-year one. American proponents of the pipeline assert the benefits of job creation and decreased American reliance on Middle Eastern oil. Opponents are concerned about the proposed route of the pipeline, the potential environmental impacts, and the resulting increase in carbon emissions upstream. Although the US Congress passed a bill in early 2015 to approve the project, State Department authorization is still needed because Keystone XL crosses over an international border. On 24 February 2015, President Barack Obama vetoed a bill approving the Keystone XL pipeline. ${ }^{31}$ At the time of writing this article, Keystone XL's future remains uncertain.

TransCanada Pipelines Limited, "Keystone XL Pipeline Project” (27 November 2013), online: <www. transcanada.com/keystone.html $>$ ["Keystone XL"]

28 Re TransCanada Keystone Pipeline GP Ltd (March 2010), OH-1-2009 at 44, online: NEB < docs.nebone. gc.ca/l1-eng/llisapi.dll/fetch/2000/90464/90552/418396/550305/604643/604441/A1S1E7 -_OH-12009 Reasons for_Decision.pdf $>$ [Re TransCanada].

29 US, Bureau of Ōceans and International Environmental and Scientific Affairs, Executive Summary Final Environmental Impact Statement for the Proposed Keystone XL Project (Washington, DC: US Department of State, 26 August 2011), online: US Department of State < keystonepipeline-xl.state.gov/ documents/organization/182010.pdf $>$.

Hoberg, supra note 6 at 378-80.

Michael D Shear \& Coral Davenport, "Obama Vetoes Bill Pushing Pipeline Approval," New York Times (24 February 2015), online: <www.nytimes.com/2015/02/25/us/politics/as-expected-obama-vetoeskeystone-xl-pipeline-bill.html?_r $=0>$. 


\section{ENERGY EAST}

On 30 October 2014, TransCanada filed a NEB application for approval of Energy East, a 4,600-kilometre pipeline that would carry 1.1-million barrels of crude oil per day from Alberta and Saskatchewan to refineries in Eastern Canada. ${ }^{32}$ Energy East would be one of the largest infrastructure projects in Canadian history.

Since its filing, TransCanada's Energy East project has already faced significant legal challenges. For example, in February 2015 the Federal Court of Canada dismissed a request to have the NEB halt its examination of the Energy East application on the grounds that the filing was made in English and not French. ${ }^{33}$ TransCanada argued that the Official Languages $\mathrm{Act}^{34}$ does not require applications to be made in both languages. The Federal Court decision acknowledged TransCanada had provided extensive translations of the Energy East project application to French speakers.

In a separate action, environmental groups in Quebec seeking to protect the St. Lawrence estuary beluga whales were successful in getting an injunction which prohibited Energy East from construction. ${ }^{35}$ On 23 September 2014, the Quebec Superior Court suspended the effect of the certificate of authorization issued to Energy East Pipeline Ltd. and TransCanada Pipelines Ltd. pursuant to section 22 of the Environment Quality Act ${ }^{36}$ until 15 October 2014. ${ }^{37}$ In early 2015 , TransCanada postponed "the planned start date for the pipeline by at least a year, to early 2020, while it studies alternative sites for a possible export facility." ${ }^{38}$

Given the economic importance of the oil sands, there is significant commercial and political pressure to increase access for new pipelines to bring product to tidewater. Resistance to new energy infrastructure - and even reconfiguration of existing facilities is more formidable, prolonged, and diverse than ever before. In 2015, no pipeline project is inevitable. What is inevitable is an increasing conflict between stakeholders and project proponents seeking expanded access to offshore markets for oil producers. How that conflict is resolved reflects the intersection of regulation, energy development, and social licence.

NEB, Media Advisory, "National Energy Board Receives Application for Energy East" (30 October 2014), online: <www.neb-one.gc.ca/bts/nws/nr/2014/mddvsrymvnrgst-eng.html> ["Media Advisory"]; Energy East Pipeline Ltd, "Volume 1: Energy East Project and Asset Transfer Applications - Executive Summary," (October 2014) at 1-1, online: <docs.neb-one.gc.ca/ll-eng/llisapi.dll/fetch/ 2000/90464/90552/2432218/2540913/2543426/2541562/Vol_1-Energy_East_Project_and_Asset_ Transfer_Applications-Executive_Summary_-_A4D8R0.pdf?nodeid $=25410178$ vernum $=-2>[$ ["Energy East Summary"].

33 TransCanada Pipelines, "Court rules against opponents trying to hold up Energy East review" (19 March 2015), online: <www.energyeastpipeline.com/court-rules-against-opponents-trying-to-hold-up-energyeast-review>; Centre québecois du droit de l'environnement v National Energy Board, 2015 FC 192, 2015 FC 192 (CanLII) (interlocutory injunction).

RSC 1985, c 31 (4th Supp).

Centre québécois du droit de l'environnement c Oléoduc Énergie Est ltée, 2014 QCCS 4398, 77 Admin LR (5th) 258 [Énergie Est].

CQLR c Q-2.

Énergie Est, supra note 35 at para 114.

Jeff Lewis, "TransCanada faces deadline pressure on Energy East proposal," Globe and Mail (12 May 2015), online: <www.theglobeandmail.com/report-on-business/industry-news/energy-and-resources/ transcanada-faces-imminent-deadline-for-energy-east-proposal/article24399398/>. 


\section{Importance of Social Licence in the Pipeline Debate}

Traditionally, developers of new pipelines in Canada relied on the legal licences that they received from applicable provincial and federal regulators, acting pursuant to specific legislation, as the legal authority needed to proceed with their projects. A licence granted by a regulator, like the NEB for an interprovincial pipeline such as Northern Gateway or Trans Mountain, meant that the proponent was generally good to go. Yes, there were a number of other technical, financial, business, and legal hurdles still to be overcome for the pipeline project, but the developer could, after a hearing — no matter how protracted and subject to meeting any conditions set out in the decision — proceed with telling all concerned that its pipeline project had been "approved" by a legally authorized public body. More importantly, it had been finally determined by that public body to be a project that was in the public interest.

This primary role of regulators, authorized by legislation, having the final say on whether or not a new pipeline project is in the public interest is being challenged today. Many stakeholders in pipeline projects advocate that a social licence granted by society, independent of legislatures, regulatory bodies, or courts, must also be obtained before any new pipeline can proceed. As one commentator put it - and the above proposed pipeline examples confirm - the NEB process is at risk of being subordinated to the "Bureau of Social Licence" where project consent is ultimately handed out by stakeholders, and not by government or governmental authorities. ${ }^{39}$

Unlike an NEB licence, a social licence is not founded in any statute or traditional rule of law and it is unclear what it actually means, who grants such a licence, what tests must be met, and when such a licence can be said to be obtained. Despite the lack of clarity, we have arrived at a point in the social licence debate where most companies in the pipeline industry acknowledge that at least the idea of a social licence is real, that it is here to stay, and that it certainly cannot be ignored by any proponent of a new pipeline in Canada. ${ }^{40}$ To ignore social licence is to risk project delays, project failure as some communities acquire de facto veto rights, ${ }^{41}$ increasing costs, and reputational risk that hinders the ability of a developer to attract skilled workers and even financial capital. ${ }^{42}$

Peter Tertzakian, "In BC, energy companies forgot about the "social licence,", Globe and Mail (6 November 2012), online: $<$ www.theglobeandmail.com/report-on-business/industry-news/energy-andresources/in-bc-energy-companies-forgot-about-the-social-licence/article4963621/>.

40 Eric Newell, "Social License is Here to Stay" (Keynote speech delivered at the TransCanada Corporation Energy Policy and Regulatory Frameworks Program at the University of Calgary School of Public Policy, 8 October 2014), online: <www.policyschool.ucalgary.ca/sites/default/files/Social\%20 licence $\% 20$ is $\% 20$ here $\% 20$ to $\% 20$ stay $\% 20$ eric $\% 20$ newell $\% 20$ oct $\% 20 \% 208 \% 202014$.pdfs.

${ }_{41}$ See e.g. Tsilhqot'in Nation v British Columbia, 2014 SCC 44, [2014] 2 SCR 257 (First Nations' potential assertion of veto rights over infrastructure projects).

42 Michael Cleland, "Unpacking Social Licence: Toward a Framework for Addressing the Social Licence Challenge Facing the Natural Resource Sector," (Discussion Paper prepared for the Honourable James A Richardson Discovery Roundtable in Victoria, British Columbia, 19 November 2013) at 1, online: Canada West Foundation < cwf.ca/pdf-docs/publications/Unpacking\%20Social\%20Licence_Fall2013 RRT.pdf $>$; Melanie Dare, Jacki Schirmer \& Frank Vanclay, "Community engagement and social licence to operate" (2014) 32:3 Impact Assessment \& Project Appraisal 188. 


\section{HiSTORY AND DEFINITION OF SOCIAL LICENCE}

Jim Cooney, an executive with Placer Dome, is often credited with coining the term social licence at a 1997 World Bank meeting examining the future survival of the mining industry. ${ }^{43}$ He actually used the phrase "social licence to operate." The phrase was an acknowledgement that the support of communities affected by mining could only be obtained and maintained if mining companies demonstrated transparency and responsibility, and entered into an open dialogue with stakeholders on the trade-offs between resource development and the environment. The social licence concept emerged as a way to include local communities in decision-making processes while paralleling the legal licensing process. ${ }^{44}$ Early scholars in the area noted, in 1973, that business could no longer equate a strong bottom line with a licence to operate, and instead needed a social contract with society whereby business became more attuned with stakeholders' needs, concerns, and expectations to achieve and maintain their right to operate. ${ }^{45}$ Not surprisingly, there is no uniform definition of social licence, though it can be said to embody the following general concepts:

1. There is a measure of confidence that society needs to have in a company that it will "behave in a legitimate, transparent, accountable and socially acceptable" manner. ${ }^{46}$ It is about building, earning and maintaining trust with people;

2. Social licence is voluntary, and therefore lacks the obligation embedded in the law as conventionally understood to be edicts of government and governmental authorities;

3. Compliance with laws and direct regulation is not sufficient for a company to obtain social licence; something more is required and "beyond compliance" behaviour is encouraged; ${ }^{47}$

4. Though not a legal contract per se, a company needs to strive to obtain an unwritten contract with society generally for the operation of its business; ${ }^{48}$

5. Social licence is often project or location specific, and there is an acknowledgment that those most affected should have the most to say about whether or not a social licence exists. ${ }^{49}$ In fact, there may not be one social licence, but a number of social licences to be obtained from different stakeholder groups $;{ }^{50}$ and

New Zealand Sustainable Business Council, "Social Licence to Operate Paper" (2013) at para 18, online: Sustainable Business Council <www.sbc.org.nz/_data/assets/pdf_file/0008/85841/Social-Licence-toOperate-Paper.pdf $>$; Jen Gerson, "Rise of 'Social licence': Claiming they speak for their community, protest groups are undermining the law," National Post (17 October 2014), online: <news.nationalpost. com/2014/10/17/rise-of-social-licence-believing-they-speak-for-their-community-protest-groups-areundermining-the-law/>.

44 Gerson, ibid.

$45 \quad$ Allan D Shocker \& S Prakash Sethi, “An Approach to Incorporating Societal Preferences in Developing Corporate Action Strategies”(1973) 15:4 California Management Rev 97 at 97.

"Social Licence to Operate Paper," supra note 43 at para 19.

For an excellent discussion of the idea of "beyond compliance" behaviour by businesses, see Neil Gunningham, Robert A Kagan \& Dorothy Thornton, "Social License and Environmental Protection: Why Businesses Go Beyond Compliance" (2004) 29:2 Law \& Soc Inquiry 307.

"Social Licence to Operate Paper," supra note 43 at para 19.

Ibid.

Dare, Schirmer \& Vanclay, supra note 42 at 189. 
6. Not only must social licence be earned, it must also be maintained as social expectations and norms change over time.

At its essence, social licence is the demand on, and expectations for, business enterprise that emerges from neighbourhoods, environmental groups, First Nations, community members, and other members of the surrounding civil society. ${ }^{51}$ Importantly, it is not a literal licensing arrangement but a "metaphor to encapsulate values, activities and ideals which companies must espouse within society to ensure successful operation." $" 52$

What kinds of issues should be relevant to whether or not a social licence is granted? At a minimum, most of society expects that businesses will not unnecessarily "negatively impact human health, the environment, or the enjoyment of property." ${ }^{53}$ However, issues such as economic fairness, cultural values, empowerment, legacy of past injustices, and trust also find their way into the search for social licence. Social licence requires companies to avoid or mitigate activities that societal groups find offensive, even if they are authorized under applicable laws. ${ }^{54}$ As such, it is another form of regulation in that (similar to applicable laws and public agency oversight) it encourages good business behaviour.

Today, the idea that compliance by companies with legal obligations does not assure compliance with social obligations has been accepted by most businesses in economically advanced democracies like Canada. Social licence issues have become part of any sophisticated risk management strategy, as "companies manage socio-political risk by conforming to a set of implicit rules imposed by their stakeholders." 55 Failure to consider social licence issues will result in a loss of reputational capital that adversely affects a company's ability to remain competitive over the long run, exposes the business to a greater risk of litigation, including regulatory enforcement, and a greater risk that government will regulate by enacting new laws in response to community dissatisfaction. These are in addition to the economic risks that failure to deal with social licence issues may negatively impact customers, who may boycott or wage social campaigns, hinder access to foreign markets, and adversely affect employee morale and recruitment.

The need for a social licence to operate is even more important in sectors with "highly visible business activities, long term horizons, high exposure to global markets, or a wide range of stakeholders keen to influence" the business. ${ }^{56}$ The pipeline industry meets each of these criteria. It is therefore not surprising that Canadian pipeline companies have recognized the importance of social licence concerns, and most have taken steps to mitigate the risk that these concerns pose to their businesses. This is often done by implementing specific policies, principles, and procedures under the general rubric of sustainable development or corporate social responsibility (CSR). In comparing social licence to CSR, one might conclude that

Gunningham, Kagan \& Thornton, supra note 47 at 308.

Sara Bice, "What Gives You a Social Licence? An Exploration of the Social Licence to Operate in the Australian Mining Industry" (2014) 3:1 Resources 62 at 64 [footnote omitted].

Gunningham, Kagan \& Thornton, supra note 47 at 314.

Ibid.

Don C Smith \& Jessica M Richards, "Social License to Operate: Hydraulic Fracturing-Related Challenges Facing the Oil \& Gas Industry" (2015) University of Denver Sturm College of Law Working Paper No 15-12 at 6, online: Social Sciences Research Network <ssrn.com/abstract=25911988>. 
social licence is the objective that is sought, while CSR is the integration of social and environmental considerations into decision-making to achieve the social licence objective.

\section{Criticism of the Social Licence Phenomenon}

It is not surprising given the ill-defined nature of social licence, as discussed above, that some critics have characterized the rise of the social licence phenomenon as a serious threat to energy development generally, and new pipeline development specifically. As a general concept that has the ability to delay or completely frustrate billions of dollars of economic development, including the new pipeline developments described above, certain commentators have rightly asked a number of critical questions. For instance, who should get to define social licence? What is the process to be followed? When has social license been granted, if it has been given at all? Is social licence defined by non-governmental organizations (NGO), government or governmental authorities, the courts, or business or public opinion? How is public or business opinion measured: through polls, demonstrations, social media comments, or elections $?^{57}$ As one critic of the concept put it:

What, for instance, is the address to which you need to write to obtain it? What form must be used? Who are the authorities entitled to decide if your application meets the rules and to whom are they accountable? In fact, what are the rules? What are the procedures followed in determining if you satisfy them? What appeal procedures exist if a project proponent feels their project has not been fairly assessed? ${ }^{58}$

To some, it is simply Not In My Backyard (NIMBY) dressed up and given another name, and has become a licence to stall as stakeholders constantly shift the social licence goal posts for project proponents. It is akin to "opponents" permission" or "mob rule" 59 that permits vital national projects to be held hostage by hard line special interest groups who oppose pipeline projects. Unfortunately, opponents can simply say that social licence has not been obtained and, given the vagueness, no one can prove them wrong. Moreover, opponents often understand social licence to mean that they, themselves, "must approve [of a project], because they equate themselves with the general public." 60

Is it nothing more than an expression of social values and political preferences by stakeholder groups disguised in legal language ${ }^{61}$ Unlike transparent public regulatory processes and bodies governed by procedural fairness, and that have formal rules and evidentiary standards founded in laws passed by democratically elected governments, social licence is arguably a tool invented to undermine the rule of law when stakeholders do not agree with a decision made by a regulatory body. As such, it is open to criticism as a term trumpeted as a justification to disregard the decisions of duly constituted democratic

57 Jeffrey Simpson, "Define 'consultation' and 'social licence"” Globe and Mail (22 October 2014), online: $<$ www.theglobeandmail.com/globe-debate/define-consultation-and-social-licence/article21199386/>. Brian Lee Crowley, "When Demands for 'Social Licence' Become an Attack on Democracy" Inside Policy (December 2014) 18 at 19, online: Macdonald-Laurier Institute < www.macdonaldlaurier.ca/files/ pdf/201412DECEMBERInsidePolicyPERRIN.pdf>.

$59 \quad$ Ibid at 21 .

60 Jeffrey Simpson, "Getting to Yes has never been tougher," Globe and Mail (27 February 2015) online: $<$ www.theglobeandmail.com/globe-debate/getting-to-yes-has-never-been-tougher/article23219918/>. A further issue is the role of advisors to stakeholders. Stakeholders are increasingly getting advice from a variety of experts, including legal consultants. Arguably, these expert consultants have played a significant role in developing the concept of social licence. 
institutions; social licence is said to represent an attack on democracy and established institutions. Proponents of social licence would say that it is simply democracy in action at a broader level, and that existing regulatory structures are nothing more than "legalism" used to suppress the views of society. Opponents to the growing importance of social licence would say that it is nothing more than "a synonym for a cool, calm, intelligent risk and reputation management" tool used by industry and government, and should never be equated to a "licence" in the legal sense. ${ }^{62}$

Despite this criticism, pipelines companies have tried to rise to the challenge. As TransCanada acknowledged in a recent CSR annual report:

Today, all of our stakeholders are rightly demanding ever-greater transparency and accountability. We continue to lead the way with actions that support our business goals and secure the social licence necessary to operate and develop the new energy infrastructure North Americans need. TransCanada's Stakeholder Relations Framework defines social licence as "the level of acceptance and approval continually granted to an organization's operations or projects by the local community and other stakeholders." As these words suggest, social licence, like our Corporate Social Responsibility program, is a journey without end. ${ }^{63}$

The need for social licence has also been acknowledged by the Alberta Energy Regulator, Enbridge, Suncor, Canadian Association of Petroleum Producers, and the Canadian Energy Pipeline Association. ${ }^{64}$

\section{Challenges in the Search FOR Social LiCEnCE}

Obtaining a social licence to develop a pipeline is difficult because every affected community of society is comprised of many different stakeholder groups that have different leaders and diverse issues. ${ }^{65}$ The array of interested constituents may be so diverse and numerous that consent from all of them becomes impossible. For example, in the pipeline context in Canada, over 20 stakeholder groups have been identified by TransCanada or Enbridge in their CSR reports as being affected by pipeline activities. ${ }^{66}$ Though there may be some commonality of interest and values, reconciling the interests and values of all of these stakeholder groups in the corporate decision-making process will require trade-offs that are very unlikely to be acceptable to all stakeholder groups or communities.

The concept of social licence creates uncertainty. Canada's energy regulatory regime is already complex. The undefined concept of social licence leads to a further lack of clarity.

62 Crowley, supra note 58 at $18-19$.

63 TransCanada Pipelines Limited, TransCanada 2013 Corporate Social Responsibility Report (2013) at 4, online: <www.transcanada.com/docs/Our_Responsibility/TransCanada-2013-CSR-Report.pdf> [TransCanada CSR Report].

64 Rowland J Harrison, "Social Licence to Operate: The Good, The Bad, The Ominous" (TransCanada Lecture in Administrative and Regulatory Law delivered at the Faculty of Law, University of Alberta, 10 March 2015) [unpublished] at 2-4 [Harrison, "Social Licence"].

65 Kathleen M Wilburn \& Ralph Wilburn, "Achieving Social Licence to Operate Using Stakeholder Theory" (2011) 4:2 J Intl Business Ethics 3 at 4-5.

66 These include community residents, media, farmers and ranchers, contractor and service providers, community investment partners, environmental and other NGOs, emergency responders, government, local municipal government, landowners, right-of-way communities, local businesses, customers, educators, industry associations, indigenous peoples, debtholders, shareholders (retail and institutional), regulators, and employees: see e.g. TransCanada CSR Report, supra note 63. 
It may be interpreted to suggest that, not only is social licence required for project development, but also that regulators need a social licence themselves to regulate. ${ }^{67}$ Failure to obtain a licence — or a challenge to regulators' ability to even issue a licence — are substantial barriers to proceed and result in potential investment and business risk.

Even if one could identify all the stakeholders and all their specific issues, many of the social and environmental issues likely to be relevant are not easily measured. As such, it is difficult to assemble and report data in an understandable and transparent manner to stakeholders for their consideration. This creates a serious challenge as developers try to deflect the arguments made by pipeline opponents on the basis of a lack of social licence. Furthermore, there are no defined processes to follow, leaving the seeker of social licence to try and determine whether there is consensus in the community and what exactly represents an adequate level of consent.

The need for actual consent for a social licence is the subject of much debate. Some people question whether there is any need in the quest for social licence for actual consent given that actual consent requires treating a community as a partner, with full information and time to make a decision as to whether to consent to the company's presence. Others, citing the United Nations Declaration on the Rights of Indigenous People, take the position that free, prior and informed consent "should be seen as the principal determinant of whether there is a 'social licence to operate' and hence is a major tool for deciding whether to support an operation." ${ }^{68}$ Clearly, the latter consent requirement would be impossible for pipeline developers to apply on a society-wide basis, though it may have some merit for smaller unique stakeholder groups who are most affected by new pipelines.

A more realistic approach to the challenges of social licence is to view it as a continuum where a company or project may achieve varying levels of social licence. It is the quality of the relationship that a company or project has with society.

\section{WHY SOCIAL LICENCE HAS BECOME Prominent in the Pipeline Debates}

So, why has social licence risen to prominence in the recent debates over new pipelines in Canada? A number of reasons may be put forward, some specific to new pipelines and others that have more general application to any new infrastructure development in today's society:

1. There has been a politicization of the regulatory process in Canada, especially with the recent federal government's overt support for energy development. For example, it has been suggested that the perceived federal support for the proposed Northern Gateway project was so heavy handed as to suggest that the NEB decision

67 Harrison, "Social Licence," supra note 64.

68 Extractive Industries Review, Striking a Better Balance: The Final Report of the Extractive Industries Review, vol 1: The World Bank Group and Extractive Industries, by Emil Salim (Jakarta: Extractive Industries Review, 2003) at 21, online: World Bank < https://openknowledge.worldbank.org/bitstream/ handle/10986/17705/842860v10WP0St00Box382152B00PUBLIC0.pdf $>$. 
could not have been made in an independent or fair manner. ${ }^{69}$ This suspicion is augmented by the fact that any NEB decision, whether positive or negative, now has to be approved by the federal Cabinet before it is effective. ${ }^{70}$ The recent election of a new NDP government in Alberta is likely to continue this politicization, albeit from a different political perspective, and further strengthen the position of social licence advocates. As British Columbia Premier Christy Clark publicly declared the day after the NDP victory in Alberta, "Albertans spoke absolutely clearly on the need for social licence when it comes to moving Alberta's heavy oil resources.... What I heard [Premier Rachel Notley] say is she believes Alberta's resources ... need to acquire social licence. I've been saying that - not to the most receptive audience initially — for a long time", ${ }^{71}$

2. The rising importance of public branding and its effect on different industries. The pipeline industry is inextricably linked to the energy industry which, unfortunately, does not have a great brand in society. ${ }^{72}$ Also, unfortunately for the energy industry, the carriers of the negative branding are often celebrities, like Neil Young, James Cameron, and Leonardo DiCaprio, as opposed to politicians and business leaders who are less trusted and listened to by the general public; ${ }^{73}$

3. A fundamental attribute of pipelines is that they are projects generally designed to get product from point A to point B and extend several hundred or thousands of kilometers. As such, they generally benefit the stakeholders at points A and B, but all the people along the pipeline route are adversely affected, and suffer ongoing risks of spills, while receiving little direct benefit. ${ }^{74}$ You can layer on to this the fact that Canada has yet to consider whether or not, as a nation, it is going to deal with the sharing of the benefits and risks associated with energy development, including pipelines, among different regions of the country ${ }^{75}$

4. There is a growing fragmentation or atomization of society, as multiple community and special interest groups have formed with interests and values that they believe should trump larger societal values. ${ }^{76}$ This can be combined with governments and businesses that think short-term and that are driven by opinion polls and quarterly

Gerson, supra note 43.

NEBA, supra note 2, s 54. In late April 2012, the federal government introduced Bill C-38, An Act to implement certain provisions of the budget tabled in Parliament on March 29, 2012 and other measures, 1st Sess, 41 st Parl, 2012, cls 68-109 (assented to 29 June 2012), SC 2012, c 19, amending NEBA, ibid. One effect of the Act was to amend the process for approving the issuance of certificates of public convenience and necessity for pipelines under NEBA. Prior to the passage of Bill C-38, the NEB could either refuse to grant such a certificate or, if the Board determined that such a certificate ought to be granted, make a recommendation to the federal Cabinet for issuance of the certificate. After the amendment by Bill C-38, the Cabinet can request further review by the NEB or decide to grant or refuse the certificate, regardless of the Board's recommendation.

Ian Bailey \& Justine Hunter, "BC premier hopeful about cooperation with Alberta after historic NDP win," Globe and Mail (6 May 2015), online: <www.theglobeandmail.com/news/british-columbia/bcpremier-says-we-have-a-lot-to-teach-alberta-after-ndps-stunning-win/article24295546/>.

For example, a CROP national opinion poll completed in October 2013 found that less than 40 percent of respondents stated that the oil and gas industry did a very good or somewhat good job of balancing economic growth and the protection of the environment. This compared with over 70 percent for the farming industry and over 60 percent for the forestry industry. See Cleland, supra note 42 at 4 .

Cleland, ibid.

Gerson, supra note 43.

Ibid.

Cleland, supra note 42 at 3. 
financial results aimed also at smaller fragmented audiences. This results in disparate groups of stakeholders looking for concepts, like social licence, that can be used to achieve their fragmented individual interests and values if traditional regulatory institutions representing broader societal interests reject their views; ${ }^{77}$

5. The rise of social media and the Internet, where both true and false information is disseminated $24 / 7$ rapidly by stakeholders in the pipeline debate, have added to the rise of social licence concepts. Organized stakeholders are more sophisticated and connected around the world than ever before, and have grabbed on to social licence as a concept that can be used to harmonize their message in social media to encourage direct participation in decision-making. The Internet and social media have given grassroots opposition a vehicle in which to mobilize and form coalitions with like-minded individuals. ${ }^{78}$ Combine this with a lack of energy literacy of many people who are not actively involved in the energy industry and the failure of business to fill in the gaps, and it is not surprising that social licence, as a perceived mandated requirement, has risen to prominence. This is equally true of nonstakeholders, individuals, and groups outside of Canada who are not directly affected by Canadian pipelines, but nonetheless express strong opinions on them and, as in the Northern Gateway and Line 9 experience, attempt to insert those opinions into the regulatory process;

6. A general fall in public confidence in business and democracy after the global financial crisis that started in 2008 and which gave rise to public protests like the "occupy movement" that suggested our democratic institutions were disproportionately benefiting business and the wealthy minority. ${ }^{79}$ Though this movement may have been viewed as radical by some, there is a growing decline in deference in our society as other well-informed and financially able members of society begin to demand better ethics, accountability, and transparency from business, all of which are wrapped up in the social licence phenomenon. Events like the BP spill in the Gulf of Mexico, the tragedy in Lac-Mégantic, and the 2010 Enbridge pipeline spill in Michigan have helped fuel this fall in public confidence;

7. There has been a generational shift in the views on the purpose behind business that has magnified the importance of companies acting in a socially acceptable manner. For example, a 2012 survey by Deloitte Touche Tohmatsu of millennials (born after 1981 , degree educated, and fully employed) in 18 countries concluded that the most common answer to the question of the purpose of business was "to improve society." ${ }^{\prime 0}$ Improving society ranked ahead of "to generate a profit" in this millennial survey. In fact, the answer "to drive innovation" ranked only slightly behind "profit generation" in the survey; 
8. New pipelines have become the lightning rod for the increasing attention that is being paid to the Alberta oil sands and the associated environmental issues that arise from the development of this energy resource. In the eyes of many stakeholders, it is not just a social licence for the pipeline that is being sought, but also a social licence for the related greenhouse gas and climate change issues. This is outside the scope of knowledge or influence of the pipeline companies or arguably the pipeline regulators. The perception of many stakeholders is that there is currently no forum where stakeholders concerned about broader policy issues, like fossil fuel use and climate change, can express their concerns, and therefore advocating for social licence in the pipeline debates may be seen as an alternative way in which these issues can be advanced and regulated. Accordingly, pipelines often become a scapegoat for stakeholders whose chief concerns are the oil sands, natural resource development and climate change;

9. First Nations and their constitutionally protected rights provide Aboriginal Canadians with a unique position when it comes to pipeline development that is, unlike social licence, grounded in the rule of law and administered by the courts. ${ }^{81}$ However, the underlying issues and interests of First Nations and their members are not dissimilar to many other stakeholder groups. Issues like economic opportunity and fairness, health and safety, and protection of the environment are common. Stakeholder groups promoting the rise of the social licence phenomenon have built off of First Nations' legally enshrined principles like information sharing, consultation and engagement, accommodation, community investment, and participation in decision-making to increase the importance of companies seeking, getting, and maintaining a social licence; ${ }^{82}$ and

10. There is no national political consensus around whether energy developments and pipeline projects are in the national interest and should proceed in certain circumstances. This creates a void as individual proponents are left to advocate for energy projects in front of regulators who have no national energy strategy or framework in which to test a project. Social licence has become a mechanism for opponents of new pipelines to fill this void.

Fundamentally, all of the foregoing reasons for the rise of the social licence phenomenon in the pipeline debates are rooted in a growing lack of public confidence and trust in government and governmental authorities to do the "right thing" in regulating business. This is where the quest for a social licence by pipeline developers intersects with government policy and highlights the role of government in the social licence debate. 


\section{IMPORTANCE AND ROLE OF GOVERNMENT IN THE SOCIAL LICENCE DEBATE}

In the current climate for pipeline development, companies are generally viewed as responsible for obtaining social licence. The role of government is sometimes obscured in the debate. However, governments, as both the regulators and the recipients of a share of resource rents, have an important role to play. They can diminish the significance of social licence by improving the regulatory processes that exist to regain public trust. Alternately, governments and regulators through legislation, public policy, or simply building public trust in institutions, can facilitate social licence and the public acceptance necessary for new energy projects. Specific examples of government's role in the social licence debate are mandated CSR and the concept of a public interest test for project development.

A chief role for governments in the social licence debate is to legislate socially and environmentally responsible practices, such as health and safety. ${ }^{83}$ This remains and has evolved into mandating CSR requirements and "sustainable" corporate practices. ${ }^{84}$ A number of European countries, for example, are actively engaged in government-driven social licence initiatives, including CSR regulation and related public policy. ${ }^{85}$ Substantively, this addresses not only corporate behaviour, but government activity such as disclosure requirements and "sustainable" government procurement. ${ }^{86}$

Between 2014 and 2015, the Canadian government itself engaged in CSR-style attempts at social licence. On 16 December 2014, the Governor General gave Royal Assent to the Extractive Sector Transparency Measures Act, sweeping legislation which establishes new mandatory reporting standards for extractive companies. ${ }^{87}$ Another example is the Canadian government's enhanced CSR strategy, Doing Business the Canadian Way: A Strategy to Advance Corporate Social Responsibility in Canada's Extractive Sector Abroad. ${ }^{88}$ In the highlights accompanying the enhanced strategy (announced on 14 November 2014), the Government of Canada states its expectation "that Canadian companies will promote

83 Laura Albareda, Josep M Lozano \& Tamyko Ysa, "Public Policies on Corporate Social Responsibility: The Role of Governments in Europe" (2007) 74:4 J Business Ethics 391 at 391-92.

84 This role is not limited to federal governments. See e.g. a discussion of the role for municipal governments in social licence: Rodney Northey, "The Role of Municipalities in Canada's Energy Strategies" (2013) 25 J Envtl L \& Prac at 135.

85 EC, Directorate-General for Employment, Social Affairs and Inclusion, Corporate Social Responsibility: National Public Policies in the European Union, by Jutta Knopf et al (Luxembourg: EC, 2011), online: $<$ ec.europa.eu/social/BlobServlet?docId=6716\&langId=en $>$.

86 Reinhard Steurer, "The Role of Government in Social Responsibility" (Proceedings of an International Workshop organized by the Government Stakeholder Group of ISO 26000, 3 November 2007), online: Institute for Managing Sustainability <www.sustainability.eu/pdf/Proceedings_ISO-Gov-Seminar_print version pics.pdf $>$.

87 SC 2014 , c 39 [ESTMA]. Its focus is on payments made to foreign and domestic governments at all levels. The purpose of these new requirements is to improve transparency within the natural resources industry and to achieve alignment with similar measures set out in the European Union and the US: see ibid, s 6; Foreign Affairs, Trade and Development Canada, Doing Business the Canadian Way: A Strategy to Advance Corporate Social Responsibility in Canada's Extractive Sector Abroad (Ottawa: FATDC, 14 November 2014) at 15, online: <www.international.gc.ca/trade-agreements-accordscommerciaux/assets/pdfs/Enhanced_CS_Strategy_ENG.pdf $>$ [Doing Business]. Key aspects of the new legislation include who is required to report, what must be reported, and the scope of compliance. While not directly related to pipeline development, it reflects another example of the federal government passing legislation to support social acceptance of the energy industry. Doing Business, ibid. 
Canadian values and operate abroad with the highest ethical standards." ${ }^{89}$ It further outlines the Government's initiatives to help Canadian companies strengthen their CSR practices internationally. ${ }^{90}$

Government-mandated CSR for the purposes of achieving social licence is not without its critics. One concern is that government involvement in corporate responsibility distorts the allocation of resources and increases the likelihood of irresponsible decisions. ${ }^{91}$ These critics state that CSR should be voluntary and that legislated CSR supresses free market activity. ${ }^{92}$

In Canada, the regulation of resource extraction is principally provincial. At the provincial level, some governments appear to have adopted social licence as a necessary element of the overall resource development process. For example, in describing the role of the recentlyestablished Alberta Energy Regulator - which may be the subject of further review by the NDP government - the Alberta Ministry of Energy acknowledges, and implicitly endorses as a matter of government policy, the need to maintain social licence:

The single regulator is one part of the province's commitment to improve integration of its resource system.

This integration sets and achieves the environmental, economic and social outcomes Albertans expect from resource development, while maintaining the social licence to develop resources. ${ }^{93}$

Both federal and provincial governments' role in the social licence debate arises from their powers to exercise reasonable control over persons and property within their jurisdictions respecting security, environment, health, safety, and welfare, among other interests. Legislatures delegate these powers to regulators and other specialized agencies, who in turn operate with a grant of power from legislation. Regulators are also subject to the rule of law, including appeals. In many cases regulators have a "public interest" mandate to determine whether projects should be approved in the public interest or collective public good. Unfortunately, respecting pipeline development, the public interest test has not been sufficient to achieve social licence.

Foreign Affairs, Trade and Development Canada, "Highlights of Canada's Enhanced Corporate Social Responsibility Strategy to Strengthen Canada's Extractive Sector Abroad" (Ottawa: FATDC, 2014), online: $<$ www.international.gc.ca/trade-agreements-accords-commerciaux/assets/pdfs/Highlights_of_ Enhanced CSR Strategy 1 page EN.pdf $>$.

90 Other proposed Canadian CSR initiatives have included: (1) a CSR framework by combining the IFC Performance Standards, Voluntary Principles on Security and Human Rights, and mandatory reporting; (2) greater disclosure at Export Development Canada; (3) independent ombudsman and tripartite compliance reviews to strengthen the role of stakeholders; and (4) a CSR centre of excellence: see Foreign Affairs, Trade, and Development Canada, Summative Evaluation of Canada's Corporate Social Responsibility Strategy For the Canadian International Extractive Sector - Final Report (Ottawa, FATDC, September 2014), online: <www.international.gc.ca/department-ministere/evaluation/2014/ seccsrscies-essrsesecpe.aspx? lang=eng $>$.

91 J Scott Armstrong \& Kesten C Green, "Effects of corporate social responsibility and irresponsibility policies" (2013) 66:10 J Business Research 1922 at 1924.

$92 \quad$ Ibid at $1926-27$.

93 Alberta Energy, "Regulatory Enhancement News and Video," online: Alberta Energy <www.energy. alberta.ca/Initiatives/3591.asp>. 


\section{The Problems of Existing Regulatory Structure AND Public Interest Test}

At the core of the existing regulatory structure for Canadian pipeline approvals - and its deficiencies - is the NEB's consideration of the public interest. The public interest has been referred to as "an empty vessel, to be filled at different times with different content." term has been synonymous with the common interest, majority interest, balance of interests, and shared values, among others. ${ }^{95}$ The definition espoused by the NEB itself is: " $t$ the public interest is inclusive of all Canadians and refers to a balance of economic, environmental, and social considerations that changes as society's values and preferences evolve over time." ${ }^{96}$

The public interest is a factor that the NEB must consider in a number of circumstances, including when the Board applies the "present and future public convenience and necessity" test under Part III of the NEBA to a proposed pipeline build. ${ }^{97}$ Its application has not only been insufficient to achieve social licence for energy project development, it has contributed to public mistrust of the government and its approval process. Problems with the public interest test include the following:

1. The term "public interest" is not defined under the NEBA or elsewhere, and the NEB has "faced ongoing challenges in articulating and applying this concept in their decisions." 98

2. The public interest test is too discretionary. In Forestethics Advocacy Association et al. v. National Energy Board et al., the Federal Court of Appeal held that the NEB has discretion in limiting the scope of what it will consider under section 52 of the NEBA and what is in the "public interest." ${ }^{\text {"99 }}$ Forestethics applied for judicial review of three decisions of the NEB where the Board ruled that certain issues, such as climate change and the environmental impacts of upstream and downstream activities, were not relevant considerations for a decision concerning a pipeline under section 52. ${ }^{100}$ The Federal Court of Appeal then found that the NEB's determination that the issues were irrelevant was reasonable. The Court noted that "[n]othing in the Act expressly requires the Board to consider larger, general issues such as climate change" and that "it was open to the Board to consider that the public interest mainly relates to the pipeline project itself, not to upstream or downstream facilities and activities."101

3. The public interest test can be inconsistent or confusing. In Northern Gateway, for example, the NEB stated that "public interest is in the interest of all Canadians."102

Mike Feintuck, 'The Public Interest' in Regulation (Oxford: Oxford University Press, 2004) at 3.

See generally Jodie L Hierlmeier, “"The Public Interest': Can It Provide Guidance for the ERCB and NRCB?" (2008) 18:3 J Envtl L \& Prac 279 at 282.

96 National Energy Board, "Strategic Plan" at n 1, online: <www.neb-one.gc.ca/bts/whwr/gvrnnc/strtgc pln-eng.pdf $>$.

NEBA, supra note 2, ss 52(1)(a), 58.16(1).

Hierlmeier, supra note 95 at 281 .

2014 FCA 245, 465 NR 152 at para 69.

Ibid at paras 1,8 .

Ibid at para 69 .

Connections, supra note 19 at 11. 
It further held that the public interest is "local, regional, and national in scope."103 It is difficult to understand - and there is little guidance from the courts - on how it can be all of these things at the same time.

4. The concept of public interest can be too narrowly interpreted. As one group of pipeline opponents asserted, the NEB "cannot determine whether the proposed pipeline is in the public interest without a full consideration of the environmental effects."104 The NEB's definition of "public interest" pushes some considerations outside of the formal legal regulatory framework. The result is stakeholders being denied an opportunity to formally express concerns about issues outside of the NEB's determination of "public interest."

5. There is insufficient transparency in regulatory decisions made in the public interest. Accordingly, the public interest can simply be used as a means to justify a decision after the fact. ${ }^{105}$ Even if there is a balancing of factors, greater transparency would enable parties to see how their interests are reflected in a decision even if ultimately it is not their interests which determine the outcome. ${ }^{106}$

One possible way of incorporating ideas of social licence into the existing regulatory model is arguably to expand the scope of the NEB's definition of "public interest" under the $N E B A$ so as to engage with a broader range of issues and interested parties. Certain authors advocate for a greater role by legislators in determining the breadth of public interest and social licence in energy matters. ${ }^{107}$ However, broadening the NEB's "public interest" standard would likely result in a more burdensome process for approvals and uncertainty about how to balance competing interests. Therefore, in its choices for energy regulatory reform models in the 2014-2015 year, the federal government wisely did not select an enhancement of the NEB's public interest test to address social licence.

\section{OVERVIEW OF 2014-2015 FEDERAL REGULATORY REFORMS IN THE SOCIAL LICENCE CONTEXT}

\section{A. Regulatory Models}

Regulatory reform is nothing new. There has been an ongoing cycle of regulatory framework examination and reform initiatives in Canada since the 1947 Statutory Orders and Regulations Order and the 1950 Regulations Act. ${ }^{108}$ The goal of "regulatory efficiency" in Canada spans almost 35 years. ${ }^{109}$ In designing its recent regulatory approach to pipeline development, the federal government therefore had several models to choose from, each

Ibid.

Mark Hume, "Group calls on NEB to revise Kinder Morgan hearing proceedings," Globe and Mail (6 May 2014), online: <www.theglobeandmail.com/news/british-columbia/restrictions-on-who-can-speakat-pipeline-hearings-unconstitutional-group-says/article18487377/>. Hierlmeier, supra note 95 at 284-85.

Ibid at 293 .

Ibid at 295-96.

For an excellent overview of the history of regulatory reform in Canada to 2006, see Judith Hanebury, "Smart Regulation — Rhetoric or Reality?" (2006) 44:1 Alta L Rev 33 at 34-39.

Ibid at $35-36$. 
involving different degrees of government control and oversight. The three most reflected in the 2014-2015 federal energy regulatory reforms are briefly described below.

\section{COMMAND AND CONTROL/ PRESCRIPTIVE REGULATION}

Command and control, or prescriptive regulation, is direct regulation by government, and centralized within a government entity. It is generally designed to prohibit or require specific activities and involves prescriptive processes that must be used, or performance results that must be achieved. ${ }^{110}$ Traditionally, the Canadian pipeline industry has been subject to a hybrid system of regulation with command and control environmental regulations, but until relatively recently - a greater degree of industry co-operation and self-regulation in the project approval and, in particular, the ratemaking process. ${ }^{111}$

Problems with a prescriptive model include expense, long enforcement processes, jurisdictional constraints, inconsistent enforcement, inflexibility, and over-formality. ${ }^{112}$ Prescriptive regulation "can be frustrating to the regulator who may find that strict legal compliance does not meet the implicit regulatory goal." 113 Governments themselves have acknowledged the inherent limits of command and control. ${ }^{114}$

\section{PERFORMANCE-BASED REGULATION}

Canadian regulation has, in recent years, moved towards performance-based regulation (PBR). PBR is not a new concept. It arose from regulators' concerns about the perceived limitations of prescriptive models and can be traced generally to the 1993 federal government report entitled Responsive Regulation in Canada,${ }^{115}$ and specifically in the Canadian pipeline context to the promulgation of the National Energy Board Onshore Pipeline Regulations ${ }^{116}$ in $1999 .{ }^{117}$

PBR is a contrasting model to prescriptive regulation. The former sets goals for behavioural outcomes while the latter establishes specific prescriptions for that behaviour. Under PBR, regulated entities are accountable for results rather than strict conformity with prescribed rules. PBR can be implemented through a number of different structures and

110 Meredith James, "Results-Based Environmental Regulation in Canada: Creative Solution or ReBranding Deregulation?" (2009) 19:2 J Envtl L \& Prac 139 at 145.

Ibid.

Ibid.

Hanebury, supra note 108 at 45.

Leslie A Pal \& Judith Maxwell, "Assessing the Public Interest in the 21st Century: A Framework" (Discussion Paper prepared for the External Advisory Committee on Smart Regulation, January 2004) at 9, online: Canadian Policy Research Networks <www.cprn.org/documents/25967_en.pdf>.

Treasury Board of Canada Secretariat, Responsive Regulation in Canada: The Government Reply to the Sub-Committee on Regulations and Competitiveness (Ottawa: Treasury Board of Canada, April 1993). The federal Regulatory Efficiency Act was introduced in 1994 but never enacted; see House of Commons Debates, 35th Parl, 1 Sess, No 138 (6 December 1994) at 8662 (Hon Arthur C Eggleton); Hanebury, supra note 108 at 37.

116 SOR/99-294 [Onshore Pipeline Regulations].

117 Hanebury, supra note 108 at 46-47. 
methodologies. These include a front-end determination of appropriate compliance burdens, regulatory flexibility, and emphasis on inspection and audits. ${ }^{118}$

The advantages of PBR over other regulatory models are well documented. They include greater effectiveness in reaching regulatory objectives, flexibility to determine regulatory outcomes, as well as greater potential for innovation, timeliness, and co-operation between regulators and regulated entities. ${ }^{119}$ Possible disadvantages arise out of PBR's strengths. Greater regulatory flexibility and scope for alternate approaches potentially result in inconsistent application of rules and lack of predictability. PBR may become so vague as to be void and therefore subject to legal challenge. ${ }^{120}$ Furthermore, both regulators and regulated entities under a PBR model can ultimately be unclear as to whether a particular goal or performance standard is met.

\section{SMART REGULATION}

A hybrid regulatory model encompassing aspects of PBR is "Smart Regulation." It employs different regulatory models, including PBR, intra- and inter-governmental cooperation, ${ }^{121}$ and timely and cost-efficient regulation. ${ }^{122}$ In 2003 the Government of Canada established the External Advisory Committee on Smart Regulation which commissioned several papers and heard submissions from interested parties. ${ }^{123}$ The Committee's mandate was to identify improvements for the Canadian regulatory system to sustain its well-being into the future.

The federal government responded in March 2005 with its Smart Regulations: Report on Actions and Plans. ${ }^{124}$ While it did not specifically address the Committee's recommendations on oil and gas, the Treasury Board indicated that it would strengthen regulatory management, improve coordination and co-operation, enhance predictability, and "create a 'life-cycle' approach that will enable regulation to be continuously improved in all sectors." 125 Concurrent with the federal government's March 2005 Smart Regulations: Report on Actions and Plans, the NEB started to implement the key aspects of Smart Regulation. ${ }^{126}$ Specific

See generally Cary Coglianese, Jennifer Nash \& Todd Olmstead, "Performance-Based Regulation: Prospects and Limitations in Health, Safety, and Environmental Protection” (2003) 55:4 Admin L Rev 705.

119 James, supra note 110 at $154,156$.

Montreal (City of) v Arcade Amusements Inc, [1985] 1 SCR 368. See also Paul Salembier, Regulatory Law and Practice in Canada (Markham: LexisNexis Canada, 2004) at 340-50.

121 The chief intergovernmental initiative by the NEB was co-ordination for the MacKenzie Pipeline Project: see generally Northern Pipeline Environmental Impact Assessment and Regulatory Chairs' Committee (Canada), Cooperation Plan for the Environmental Impact Assessment and Regulatory Review of a Northern Gas Pipeline Through the Northwest Territories (June 2002), online: Environmental Impact Screening Committee $<$ www.screeningcommittee.ca/pdf/northern_gas_coop_ plan.pdf $>$.

One example of efficiency methods at this time were the NEB's service standards: see Hanebury, supra note 108 at 52 .

Canada, Privy Council Office, Smart Regulation: A Regulatory Strategy for Canada, prepared by the External Advisory Committee on Smart Regulation, Catalogue No CP22-78/2004E, (Ottawa: PCO, September 2004) at 3,125,129, online: Government of Canada <publications.gc.ca/collections/ Collection/CP22-78-2004E.pdf>. 80/2005E-PDF (Ottawa: PCO, March 2005), online: Government of Canada <publications.gc.ca/ collections/Collection/CP22-80-2005E.pdf>.

Ibid at 9. The facilities regulations examined included the Onshore Pipeline Regulations, supra note 116; National Energy Board Processing Plant Regulation, SOR/2003-39. 
examples included the NEB's examination of facilities regulations to determine whether they raised opportunities to employ PBR, as well as its use of guidelines and audits. ${ }^{127}$

\section{B. Key 2014-2015 Pipeline ANd Social LiCEnCE Amendments}

Recent legislative initiatives by the federal government are unprecedented changes in the political and legal landscape for pipelines in Canada. These changes create a new regulatory framework at a time when achieving social licence for natural resource projects has never been a greater commercial risk. The common thread which weaves its way throughout the federal reforms is a move towards a more prescriptive regime, presumably to achieve greater societal acceptance of Canadian pipeline projects.

Ottawa's Responsible Resource Development Plan, announced as part of Economic Action Plan 2012, is the policy basis for recent federal regulatory energy reforms. These commenced in 2012 with amendments to the $N E B A^{128}$ and have continued into 2015 with the Pipeline Safety Act. ${ }^{129}$ The changes to the federal energy regulatory regime are too numerous to address all within the scope of a single article. Accordingly, this article only focuses on the amendments and policy development occurring in 2014 and the first half of 2015 which are relevant to both pipeline development and social licence.

\section{RESPONSIBLE RESOURCE DEVELOPMENT PLAN}

Changes introduced under the Responsible Resource Development Plan reflect four key themes: (1) more predictable and timely project reviews; (2) reduced duplication in the review process; (3) strengthened environmental protection; and (4) enhanced consultations with Aboriginal Peoples. ${ }^{130}$ Its intent was to capitalize on Canada's energy wealth to create jobs and prosperity for Canadians, while ensuring safety and environmental protection. Further specifics of the 2012 policy included "[m] oving toward a 'one project, one review' system for reviews of major projects" and "[s] etting timelines for hearings and assessments, namely, 24 months" for projects under the Canadian Environmental Assessment Act, 2012, ${ }^{131}$ 18 months for projects under the NEBA, and 12 months for standard environmental assessments conducted by the Canadian Environmental Assessment Agency. ${ }^{132}$

To fulfill the policy objectives of the Responsible Resource Development Plan, the federal government enacted the CEAA and undertook amendments to the NEBA. These redefined the NEB's role in the pipeline approval and related environmental assessment processes. ${ }^{133}$ The federal government's 2014 and 2015 legislative agendas for resource development, described

Ibid at 46-47.

NEBA, supra note 2, as amended by Jobs, Growth and Long-term Prosperity Act, SC 2012, c 19 (assented to 29 June 2012).

Bill C-46, An Act to amend the National Energy Board Act and the Canada Oil and Gas Operations Act, 2nd Sess, 41st Parl, 2015 (assented to 18 June 2015), SC 2015, c 21 [Pipeline Safety Act].

Government of Canada, "Responsible Resource Development - Overview," online: Canada's Economic Action Plan <www.actionplan.gc.ca/en/page/r2d-dr2/overview>.

SC 2012, c 19, s 52 [CEAA].

Natural Resources Canada, News Release, "Harper Government Announces Plan for Responsible Resource Development" (17 April 2012), online: <www.nrcan.gc.ca/media-room/news-release/2012/ $45 / 2001>$.

See Rowland J Harrison, Lars Olthafer \& Katie Slipp, "Federal and Alberta Energy Project Regulation Reform - At What Cost Efficiency?" (2013) 51:2 Alta L Rev 249 at 251. 
in detail below, contain further initiatives to fulfill the intent of the Responsible Resource Development Plan in support of building pipelines and developing market access. ${ }^{134}$

\section{PIPELINE SAFETY ACT}

On 8 December 2014, Canada's Minister of Natural Resources introduced Bill C-46, entitled the Pipeline Safety Act. It received Royal Assent on 18 June $2015 .^{135}$ The Pipeline Safety Act amends the NEBA and the COGOA to increase NEB oversight powers respecting pipeline safety and pipeline operators' liability. Together with new rail safety and tanker safety regulations, these regulatory changes enhance the federal regime for transporting oil, petroleum, and natural gas products.

The Pipeline Safety Act will essentially place a new, significant onus on pipeline companies to ensure that operations do not result in releases of oil, gas or other related commodities and that necessary financial resources are available to meet any liability. That Act allows the Governor-in-Council to establish a Pipeline Claims Tribunal to examine and adjudicate compensation claims for damage caused by an unintended or uncontrolled release of oil, gas, or any other commodity from a pipeline. ${ }^{136}$ It further sets out the tribunal's hearing process. ${ }^{137}$

\section{OFFSHORE HEALTH AND SAFETY ACT}

In June 2014, the federal Offshore Health and Safety Act received Royal Assent. ${ }^{138}$ It "establishes a new occupational health and safety regime applicable to workplaces in the offshore areas of Newfoundland and Labrador and of Nova Scotia." ${ }^{39}$ Respecting pipeline interests, the key provision is that the definition of "marine installation or structure" set out at section 138 of the OHSA includes pipelines. ${ }^{140}$ This may necessitate additional vigilance and clarifies safety requirements and responsibilities for those companies involved in the operation and maintenance of pipelines associated with the offshore industry. Other key enactments under the OHSA include clarification of the respective safety responsibilities for the offshore boards, the federal government, and the provincial governments and establishing a new appeal process. ${ }^{141}$

House of Commons Debates, 41st Parl, 2nd Sess, No 162 (26 January 2015) at 10557-60 (Hon Greg Rickford).

Pipeline Safety Act, supra note 129.

Ibid, c1 16, amending NEBA, supra note 2, ss 48.18-48.34.

Ibid, amending NEBA, ibid, ss 48.35-48.42, 48.46.

SC 2014, c 13 [OHSA],

Library of Parliament, Legislative Summary of Bill C-5 An Act to Amend the Canada-Newfoundland Atlantic Accord Implementation Act, the Canada-Nova Scotia Offshore Petroleum Resources Accord Implementation Act and Other Acts and to Provide for Certain Other Measures, by Penny Becklumb et al, Publication No 41-2-C5-E (Ottawa: LOP, 28 October 2013) at 1, online: LOP <www.parl.gc.ca/ content/LOP/LegislativeSummaries/41/2/C5-e.pdf $>$ [footnote omitted] [Legislative Summary]. 


\section{2014 ABORIGINAL ECONOMIC DEVELOPMENT PROGRESS REPORT}

This article only highlights the status of new Aboriginal consultation initiatives which the federal government undertook in 2014-2015. Aboriginal engagement and consultation is a part of the federal government's Responsible Resource Development Plan. Key measures to support Aboriginal consultation under that policy include:

- Integrating consultation into the project review process to ensure early consideration of potential impacts to Aboriginal or treaty rights before decisions are made;

- Designating a lead department or agency to coordinate consultations for each project review;

- Providing additional funding of $\$ 13.6$ million over two years to support Aboriginal consultations on projects; and

- Developing consultation memoranda of understanding and protocols with provinces and Aboriginal groups to align processes and clarify expectations. ${ }^{142}$

The federal government has not implemented the consultation aspects of the Responsible Resource Development Plan. However, it released its Federal Framework for Aboriginal Economic Development Progress Report in June 2014. ${ }^{143}$ This report indicates that regulatory and consultation reform is forthcoming and would operate in tandem with similar provincial initiatives. No further specifics to the federal government's proposed Aboriginal consultation guidelines referenced in the 2014 report have been released at the time of writing.

\section{WHAT CHOICES DO THE 2014-2015 FEDERAL REgULATORY REFORMS REFLECT?}

The 2014-2015 regulatory reforms represent a movement towards a hybrid of prescriptive and PBR regulatory models. They further reflect the social licence encompassed in CSR principles.

The Pipeline Safety Act is a more prescriptive regulatory pipeline regime for reasons which include the following:

1. The Pipeline Safety Act adds section 48.12(4) to the NEBA; an additional provision which makes all companies who operate a pipeline absolutely liable, without proof peoples-participation-canadas-resource>.

143 Canada, Minister of Aboriginal Affairs and Northern Development, Federal Framework for Aboriginal Economic Development: Progress Report, Catalogue No R3-75/4-2014E-PDF (Ottawa: AANDC, June 2014), online: <www.aadnc-aandc.gc.ca/DAM/DAM-INTER-HQ-ECD/STAGING/texte-text/fed_ Framework_Progress_Report_June_2014_1405522723342_eng.pdf $\$$ [Federal Framework]. 
of fault or negligence, for any releases from a pipeline, up to a limit of liability for major pipelines (over 250,000 barrels/day) of \$1 billion; ${ }^{144}$

2. Pipeline companies and any other persons who by fault or negligence cause a spill, are now jointly and severally liable for a variety of damages, including all actual loss or damage caused to any person and by any person in response to an incident; ${ }^{145}$

3. The NEB may direct any company that operates a pipeline from which an unintended or uncontrolled release of oil, gas, or any other commodity occurs, to reimburse government institutions for costs incurred in taking any action respecting the release, ${ }^{146}$

4. The NEB may order pipeline companies to remain responsible over, and to maintain funds to pay for, the abandonment of their pipelines; $;{ }^{147}$

5. There are new statutory causes of action for both fault and absolute liability claims and a limitation period of three and not more than six years. ${ }^{148}$ This is longer than the standard two-year limitation period in most limitation statutes;

6. The NEB may take, under certain circumstances, any action it considers necessary, including response and clean up, respecting an unintended or uncontrolled release of oil, gas, or any other commodity from a pipeline; ${ }^{149}$ and

7. The new legislation mandates that pipeline companies hold a minimum level of financial resources, set at $\$ 1$ billion for companies operating major pipelines. These funds are required to be readily accessible to ensure rapid response to any incident. ${ }^{150}$ A company may create a "pooled fund" to hold these minimum levels of financial resources. $^{151}$

The 2014-2015 regulatory amendments also reflect PBR principles. ${ }^{152}$ These include results-based approaches for broader contextual issues such as pipeline safety and environmental protection. They further utilize risk assessment and emphasis on inspection and audits for meeting specified goals. This is demonstrated in an expansion of the NEB's audit and inspection powers and under the Pipeline Safety Act. The Act enshrines, for the first time in NEB legislation, the "polluter pays" principle, making pipeline companies

Pipeline Safety Act, supra note 129, cl 16. While beyond the scope of an article on 2014-2015 reforms, even more onerous are the amendments made to the Onshore Pipeline Regulations, supra note 116 on 10 April 2013. They require, among other things, pipeline companies to establish, implement and maintain management systems and protection programs. The guidelines for these requirements are exceptionally detailed and offer little ability for companies to determine how they best comply. For example, the regulations and related guidelines go so far as to cite ISO 9000, the international quality assurance program, as the standard for choosing pipeline materials and demonstrating adequacy and effectiveness of management processes employed. Pipeline Safety Act, ibid, cl 16, amending NEBA, supra note 2, ss 48.12(1)-(3).

Pipeline Safety Act, ibid, amending NEBA, ibid, s 48.15. Pipeline Safety Act, ibid, amending NEBA, ibid, s 48.49.

Pipeline Safety Act, ibid, amending NEBA, ibid, ss 48.12(10)-(12).

Pipeline Safety Act, ibid, amending NEBA, ibid, ss 48.16-48.17, 48.46.

Pipeline Safety Act, ibid, amending NEBA, ibid, s 48.13.

Pipeline Safety Act, ibid, amending NEBA, ibid, s 48.14.

For a discussion of those principles, see generally Coglianese, Nash \& Olmstead, supra note 118. 
responsible for the costs and damages they cause through the release of oil, gas, or any other commodity from a pipeline. ${ }^{153}$ This is arguably both a PBR and prescriptive concept because it not only mandates behaviour, but also provides flexibility in how to comply.

The 2014-2015 changes do not reflect a full PBR system: (1) they have limited regulatory flexibility; and (2) they largely rely upon enumerated requirements rather than more selfregulating ones such as guidelines and codes of conduct. This is because of the addition of absolute liability offences and liability limits without proof of fault or negligence, which remove regulatory flexibility and discretion in determining fault, liability, and sanctions.

In attempting to achieve social licence, the third area which the 2014-2015 reforms draw from is CSR. The 2014-2015 reforms are not CSR-specific legislation for pipelines in the same way that the ESTMA is for extractive industries. However, the areas addressed in most recent CSR reports from Canadian pipeline companies dove-tail with the intent of the Pipeline Safety Act. TransCanada Pipelines' CSR, for example, is largely devoted to describing its health, safety, and environmental stewardship programs for its pipeline system. ${ }^{154}$ These are the same areas targeted by the $2014-2015$ reforms.

The federal government's policy choices in the late 2000s were largely initiatives to reduce regulation, perhaps most significantly the federal government's 2007 "Cabinet Directive on Streamlining Regulation." ${ }^{\text {"155 }}$ Regulation in an era of social licence is now inconsistent with those federal streamlining initiatives of the late 2000s. The result is that Ottawa's framework for the natural resource and pipeline industry regulation as set out in 2014-2015 legislative amendments is more of a PBR and prescriptive design hybrid, reflecting the NEB's use of Smart Regulation in the pre-streamlining era of the early to mid2000s. It further encompasses CSR principles. The larger question is, did the reforms go far enough to help business achieve a social licence to develop new pipelines?

\section{DO THE 2014-2015 FEDERAL REGULATORY REFORMS Go FAr EnOUgh to ACHIEVE Social LiCENCE?}

The vagueness of the social licence concept means that it does not necessarily conform to rules and compliance methods established by traditional regulatory frameworks such as the Pipeline Safety Act. The new 2014-2015 regulatory regime is more stringent on environmental protection and pipeline safety than its predecessor. As such, it should help achieve greater public acceptance for pipeline projects. However, there are several gaps in the 2014-2015 federal reforms which may reduce the impact they have on the search for social licence for pipeline projects: BT22-110/2007 (Ottawa: TBCS, 2007), online: Government of Canada < publications.gc.ca/collections/ Collections/BT22-110-2007E.pdf>. The Directive is a document setting out the frameworks and legislation that support the federal regulatory process. It is a reference tool for federal departments and agencies when they are developing, implementing, evaluating, and reviewing federal regulations. It outlines best practices for the process of designing regulations, and it points out the associated requirements. It also explains the roles of key departments and agencies responsible for the regulations. 
1. The 2014-2015 reforms do not address climate change, an important element of social licence for energy projects. The NEB stated that it does not consider upstream or downstream climate change in a broad sense; only direct emissions or those that have a nexus or direct connection with the particular pipeline project under review. ${ }^{156}$ None of the 2014-2015 reforms address this, which may ultimately challenge the energy sector generally, and the pipeline industry more particularly, to achieve social licence.

2. Nothing in the 2014-2015 reforms safeguard stakeholders' procedural interests. The 2012 streamlining process for NEB regulatory decision-making remains in place, as does final Cabinet approval over project applications to the Board. If anything, as some critics contend, these concerns are reinforced in 2015 by the Pipeline Safety Act, which gives significant discretion to the federal Cabinet as to what extent or even whether, that statute's "teeth" are used. ${ }^{157}$ The 2014-2015 pipeline reforms therefore reinforce concerns respecting the NEB's independence raised in the 2012 amendments to the NEBA. Specifically, that the NEB has become less independent and that its role is as a body that makes recommendations to Cabinet rather than as a decision-maker itself. ${ }^{158}$

3. While the statements on Aboriginal engagement in the Responsible Resource Development Plan and the June 2014 Federal Framework have the potential to support social licence with Aboriginal groups, they remain unimplemented. The Federal Framework states an intent to "[w]ork with other partners to reform the regulatory system in support of resource development to provide predictable, certain and timely reviews, reduce duplication, and strengthen and enhance Aboriginal consultations" and further recommends implementing a "governance structure to better coordinate support for Aboriginal participation in major projects." 159 To the extent that the Federal Framework facilitates greater economic participation in energy projects, it is presumably closer to achieving social licence objectives. However, the absence of regulatory amendments to enhance the federal consultation process is a clear social licence gap, albeit one that may be remedied. A potential model is the 2014 Alberta amendments which enhance conditions for successful consultation through the creation of the Aboriginal Consultation Office and determination of clear roles vis-à-vis the Alberta Energy Regulator. ${ }^{160}$ This fosters greater certainty,

See generally Jocelyn Stacey, "Failing to Assess the Key Issue: The Unsatisfactory Approval Process for Keystone XL" (25 September 2001), Ablawg (blog), online: <ablawg.ca/2011/09/25/failing-toassess-the-key-issue-the-unsatisfactory-approval-process-for-keystone-xl/>. See also Re TransCanada, supra note 28 at 74-75 (where the NEB held that it would not consider the upstream or downstream facilities either under the $N E B A$ or $C E A A$, as these effects were considered too remote and outside the scope of the environmental assessment, and because oil sands or refining facilities would be regulated by other governments or operated by other companies).

See e.g. Ian Miron, "Bill C-46: What it means for pipelines, polluters and you" (6 January 2015), EcoJustice (blog), online: $<$ www.ecojustice.ca/blog/bill-c-46-what-it-means-for-pipelines-polluters-andyou $>$. See also amendments to $N E B A$, supra note 2, s 48, which give the federal Cabinet significant powers.

Rowland J Harrison, "The Elusive Goal of Regulatory Independence and the National Energy Board: Is Regulatory Independence Achievable? What Does Regulatory 'Independence' Mean? Should We Pursue It?"(2013) 50:4 Alta L Rev 757 at 775. 
predictability and a coordinated process. If federal consultation guidelines are revised in a manner complimentary to their Alberta counterpart, it would be a potentially positive step for pipeline proponents in streamlining effective consultation.

4. The environmental penalties of the Pipeline Safety Act, while enhanced, may not go far enough. The new legislation does not identify absolute liability limits for gas and other non-oil pipeline companies or impose unlimited absolute liability on polluters. It caps liability at $\$ 1$ billion and requires pipeline companies to hold $\$ 1$ billion in financial resources to address pollution. Arguably, no liability regime can truly be called a "polluter pays" regime unless and until polluters are made absolutely liable for the full costs of environmental harm.

5. It is unclear who pays for pipeline pollution incidents with impacts of over \$1 billion. This raises the issue of whether social licence is only achievable through unlimited liability. Further clarity is needed on whether pollution impacts of over $\$ 1$ billion become public costs. Moreover, the Pipeline Safety Act is silent on identifying absolute liability limits for smaller oil pipeline companies, or for gas and other non-oil pipeline companies.

6. The areas addressed in the 2014-2015 reforms mirror the issues covered in CSR reports of major pipeline companies. It is unclear whether those companies are achieving social licence through their current CSR programs. Moreover, CSR programs are including their greenhouse gas initiatives, ${ }^{161}$ conspicuous by its absence in federal government policy.

7. Finally, the 2014-2015 reforms do not fully address the broader public divide in Canada on the social benefits and burdens of energy development. Critics of federal energy policy allege that the implementation of the Responsible Resource Development Plan is not about achieving social licence at all, but rather is "focused on the development and export of petroleum and natural gas resources, and the removal of perceived environmental constraints on that path." 162 Moreover, there is nothing in the post-2012 regulatory changes which addresses the concerns of, and impacts to, non-petroleum exporting provinces, such as income disparity and the regional inequalities in capturing value from Canada's natural resources.

\section{SOCIAL LICENCE ROLE FOR BUSINESS LAWYERS}

We would be remiss if we did not take a moment to highlight the significant role that business lawyers have in assisting their pipeline clients in the search for social licence. It is not just the government and its regulators that can assist business in this quest. Business lawyers are often either the interface between a pipeline developer and the stakeholders, or are directly involved in preparing agreements and other materials that will be presented to stakeholders. Thus, business lawyers must be cognizant that protection of their client's legal 
interests is reconciled with the transparency and open dialogue necessary to help acquire stakeholder support. Besides the legal contract, a social contract is being sought by clients. As a result, stakeholder needs, concerns, and expectations will have to be listened to, understood, and met, despite the negative impact that these may have on legally enshrined rights.

Trust is not built and maintained by presenting stakeholders with legal agreements and other materials that are long, difficult to understand, and appear one-sided. As noted above, the search for social licence often requires that pipeline developers exhibit "beyond compliance" behaviour. This takes creative solutions that often do more for stakeholders than the law requires. However, the socio-political risks that come with doing less may well threaten the viability of the whole pipeline project that is sought to be built. If business lawyers become overly focused on the law and historical legal precedents, and are not prepared to help with creative solutions that balance stakeholder-business interests, then other non-legal business advisors will fill the gap. The role of the business lawyer as a narrowly-focused advisor risks being diminished over time. However, the quest for social licence is an emerging area in which innovative business lawyers can bring value-added advice to clients.

\section{CONCLUSIONS}

Social licence is largely untested as a regulatory concept, but may be considered a form of civil regulation by drawing from market forces and norms that encourage certain types of behaviour. Canadian energy regulators rarely refer to social licence. It is nonetheless a de facto form of regulation because there are consequences for failing to comply with social licence conditions, such as reputational damage and delay or ultimately preclusion of a natural resource project. While it does not establish a new legal or regulatory requirement, social licence can push the boundaries of existing ones, such as the NEB's public interest test.

Governments have a role in the social licence debate. The 2014-2015 reforms reflect a fundamental transformation not only in the way pipelines will be regulated, but also a continuation of the federal government's approach to help achieve social licence for Canadian energy infrastructure development that commenced in 2012 with the Responsible Resource Development Plan. It is a response to the rising prominence of social licence generally, and the challenges facing current Canadian pipeline projects in particular. In responding, the federal government has drawn from more prescriptive models of regulation and CSR principles.

It is debatable whether energy regulators should be trying to address the social licence issue. Regulators are not required by law to "win over" project opponents. The standard for them is instead the average reasonable person or what Lord Denning referred to as the "man on the Clapham omnibus" would think. Lord Denning did not mean something obscure, but rather "the standard by which legal decisions are always measured, namely what an average reasonable person would conclude if he or she were in possession of all the relevant facts and 
arguments, which is what a legal proceeding is designed to elicit." 163 This is precisely the purpose of NEB and other regulatory proceedings — "to create a fair setting where all relevant information is gathered and independent and disinterested commissioners ask themselves what a reasonable person would conclude about the balance between the costs and benefits of the project before them." ${ }^{164}$ In other words, the very phrase "the public interest" to be considered by the NEB implies an overall balancing of various, competing societal interests. ${ }^{165}$

It is possible that the federal government amendments since 2012 to help regulators do precisely what Lord Denning had envisioned. The amendments also acknowledge the meaningful intersection between regulation and social licence and may help to ensure that a pipeline company does not find itself with an NEB pipeline approval but without a social licence to construct and operate that pipeline. Time will tell but, in the meantime, Canada remains a Continental oil price taker and energy superpower in waiting as pipeline developers struggle to reconcile these social and regulatory issues.

163 Crowley, supra note 58 at 2.

165 Harrison, "Social Licence," supra note 64 at 5. 


\section{APPENDIX A}

\begin{tabular}{|c|c|c|}
\hline $\begin{array}{l}\text { Proposed Canadian } \\
\text { Pipeline Projects }\end{array}$ & Project Status & PiPELINE CAPACITY \\
\hline $\begin{array}{l}\text { Enbridge Alberta Clipper } \\
\text { (Line 67) }\end{array}$ & $\begin{array}{l}\text { Enbridge received approval from the NEB in February } 2013 \text { to } \\
\text { proceed with the modifications to the existing facilities. }{ }^{166}\end{array}$ & $\begin{array}{l}\text { Expansion from } 450,000 \\
\text { bpd to } 570,000 \text { bpd } \\
\text { Hardisty, Alberta to the } \\
\text { US border near Gretna, } \\
\text { Manitoba }^{167}\end{array}$ \\
\hline $\begin{array}{l}\text { TransCanada } \\
\text { Energy East }\end{array}$ & $\begin{array}{l}\text { TransCanada filed its application with the NEB on } 30 \text { October } \\
2014 .^{168} \\
\text { The NEB issued two Lists of Issues in relation to the Energy } \\
\text { East project, one for Physical Facilities Matters }{ }^{169} \text { under Part } \\
\text { III of the NEBA and another for Commercial and Financial } \\
\text { Matters }{ }^{170} \text { under Part IV and Part V of the Act. } \\
\text { The NEB is currently reviewing the application and has not yet } \\
\text { made any determination on its completeness. }{ }^{171}\end{array}$ & $\begin{array}{l}\text { 1,100,000 bpd } \\
\text { 4,500 kilometres } \\
\text { Hardisty, Alberta to St. } \\
\text { John, New Brunswick } \\
\text { area }^{172}\end{array}$ \\
\hline Enbridge Line 9 & $\begin{array}{l}\text { On } 2 \text { March } 2014 \text {, the NEB approved Enbridge's application to } \\
\text { reverse the segment of its existing } 639 \text { kilometre Line 9B } \\
\text { between North Westover, Ontario and Montreal, Quebec, in } \\
\text { addition to expanding the entire Line } 9 \text { capacity from Sarnia, } \\
\text { Ontario to Montreal, and permitted the transportation of heavy } \\
\text { crude. }{ }^{173} \\
\text { On } 6 \text { October } 2014 \text {, the NEB found Enbridge failed to meet } \\
\text { condition } 16 .{ }^{174} \text { They must refile condition } 16 \text { before applying } \\
\text { for leave to open. }\end{array}$ & $\begin{array}{l}\text { Increase capacity from } \\
240,000 \text { bpd to } 300,000 \\
\text { bpd } \\
639 \text { kilometres } \\
\text { North Westover, Ontario } \\
\text { to Montreal, Quebec }{ }^{175}\end{array}$ \\
\hline
\end{tabular}

Enbridge Inc, "Alberta Clipper (Line 67) Capacity Expansion,” online: <www.enbridge.com/Mainline EnhancementProgram/Canada/Alberta-Clipper-Capacity-Expansion.aspx $>$.

Ibid.

"Media Advisory," supra note 32.

National Energy Board, "Eastern Mainline Project," online: <www.neb-one.gc.ca/pplctnflng/mjrpp/ strnmnln/index-eng.html\#s3>.

National Energy Board, "TransCanada Energy East Pipeline Project - List of Issues," online: <www.nebone.gc.a/pplctnflng/mjrpp/nrgyst/nrgystlstfsss-eng.html>.

National Energy Board, "Energy East Project, online: <www.neb-one.gc.ca/pplctnflng/mjrpp/nrgyst/ index-eng.html >.

"Energy East Summary," supra note 32 at 1. See also TransCanada Pipelines Limited, "Energy East Pipeline Project," online: <www.transcanada.com/energy-euof-Pipeline.html>.

Re Enbridge, supra note 24 at 1, 3.

Letter from National Energy Board to Enbridge Pipelines Inc (6 October 2014), online: NEB < docs.nebone.gc.ca/ll-eng/llisapi.dll/fetch/2000/90464/90552/92263/790736/890819/2432299/2525879/Letter to_Enbridge_Pipelines_Inc._Condition_16_Filing___Line_9_Intelligent_Valve_Placement ${ }_{-}^{-}$

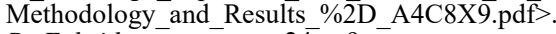

Re Enbridge, supra note $2 \overline{4}$ at 9. 


\begin{tabular}{|c|c|c|}
\hline $\begin{array}{l}\text { Proposed CANAdian } \\
\text { PiPEline Projects }\end{array}$ & Project Status & PiPeline CAPACity \\
\hline $\begin{array}{l}\text { TransCanada } \\
\text { Keystone XL }\end{array}$ & $\begin{array}{l}\text { US - It has been approved by the US Congress, but not the } \\
\text { State Department. Further, US President Obama has vetoed the } \\
\text { project. } \\
\text { Canada - On } 27 \text { February } 2009 \text {, Keystone filed an application } \\
\text { with the NEB requesting approval to construct and operate the } \\
\text { Canadian portion of the Keystone XL Pipeline. The NEB } \\
\text { issued its approval in March } 2010 .{ }^{176}\end{array}$ & $\begin{array}{l}1,291,000 \text { bpd }^{177} \\
\text { 1,897 kilometres, 36-inch } \\
\text { diameter crude oil } \\
\text { pipeline }^{178}\end{array}$ \\
\hline $\begin{array}{l}\text { Enbridge Northern } \\
\text { Gateway }\end{array}$ & $\begin{array}{l}\text { On } 17 \text { June 2014, the Joint Review Panel approved the } \\
\text { Northern Gateway project, subject to } 209 \text { conditions that must } \\
\text { be met before construction of the pipeline begins. }{ }^{179}\end{array}$ & $\begin{array}{l}\text { The westbound 36-inch } \\
\text { diameter pipeline will } \\
\text { carry up to } 525,000 \\
\text { barrels of oil per day. The } \\
\text { eastbound } 20 \text {-inch } \\
\text { diameter pipeline will } \\
\text { carry } 193,000 \text { barrels of } \\
\text { condensate per day }{ }^{180} \\
\text { 1,778 kilometres }{ }^{181} \\
\text { Edmonton, Alberta }{ }^{182} \text { area } \\
\text { to marine terminal in } \\
\text { Kitimat, British Columbia }\end{array}$ \\
\hline $\begin{array}{l}\text { Kinder Morgan Trans } \\
\text { Mountain }\end{array}$ & $\begin{array}{l}\text { On } 16 \text { December } 2013 \text {, Kinder Morgan filed a facilities } \\
\text { application to the NEB for the proposed Trans Mountain } \\
\text { pipeline expansion. }{ }^{183} \text { If the regulatory application process is } \\
\text { successful, construction of the new pipeline could begin as } \\
\text { early as } 2016 \text {. The expanded pipeline would be operational in } \\
\text { late } 2018 \text {. }\end{array}$ & $\begin{array}{l}\text { Increase capacity from } \\
300,000 \text { bpd to } 890,000 \\
\text { bpd }^{184} \\
1,100 \text { kilometres }^{185} \\
\text { Edmonton, Alberta to } \\
\text { Burnaby, British } \\
\text { Columbia }\end{array}$ \\
\hline
\end{tabular}

Re TransCanada, supra note 28 at 5.

Ibid at 44.

"Keystone XL," supra note 27.

Connections, supra note 19 at 71 .

Ibid at 3.

Ibid at 4.

Ibid at 32 .

Kinder Morgan, "Trans Mountain Pipeline Expansion Project,” online: <www.kindermorgan.com/ pages/business/canada/tmx_expansion.aspx $>$.

Ibid.

Penner, supra note 14. 


\begin{tabular}{|l|l|l|}
\hline $\begin{array}{l}\text { Proposed Canadian } \\
\text { PIPEline Projects }\end{array}$ & Project Status & PIPELine CAPACITY \\
\hline $\begin{array}{l}\text { TransCanada } \\
\text { Upland }\end{array}$ & $\begin{array}{l}\text { TransCanada plans to submit an application to the US State } \\
\text { Department in the second quarter of 2015. The company will } \\
\text { also need approval from North Dakota's Public Service } \\
\text { Commission and the NEB. Projected to be operational in } \\
2018 .{ }^{186}\end{array}$ & $\begin{array}{l}\text { Approximately } 300,000 \\
\text { bpd }\end{array}$ \\
& $\begin{array}{l}400 \text { kilometres } \\
\text { Williston, North Dakota } \\
\text { to Manitoba- } \\
\text { Saskatchewan border }{ }^{187}\end{array}$ \\
\hline
\end{tabular}

186 TransCanada Pipelines Limited, News Release, "TransCanada Reports Strong Fourth Quarter and YearEnd Financial Results" (13 Feburary 2015), online: <transcanada.mwnewsroom.com/files/5b/5b4 ab869-835d-472c-b843-b8d49da7c23b.pdf $>$.

187 TransCanada Pipelines Limited, "Proposed Upland Pipeline," online: <www.transcanada.com/uplandpipeline.html>. 